\title{
Assessment of DNA Damage in Peripheral Blood Leukocytes of Patients with Essential Hypertension by the Alkaline Comet Assay
}

\author{
Gursatej Gandhi* and Jeevan Jyoti \\ Department of Human Genetics, Guru Nanak Dev University, Amritsar 143 005, India
}

Received October 6, 2009; accepted May 6, 2010

\begin{abstract}
Summary DNA damage was assessed in 50 subjects using the alkaline Single Cell Gel Electrophoresis assay and included 35 (18 males, 17 females) hypertensive individuals and 15 (7 males, 8 females) normotensives of the same age, sex and socio-economic status. Patients (32-62 years) had average systolic blood pressure $>156 \mathrm{mmHg}$, diastolic pressure $>98 \mathrm{mmHg}$, pulse and arterial pressure of $>56$ and $>116 \mathrm{mmHg}$, respectively. Average BMI was $25.18 \mathrm{~kg} / \mathrm{m}^{2}, 54 \%$ were overweight, $16.45 \%$ obese and waist hip ratio (WHR) $>0.95$. Chi-square test revealed that controls matched patients except for blood pressure values. Multiple regression analysis and analysis of variance (ANOVA) showed that DNA damage significantly associated with systolic $(p<0.05)$, diastolic blood pressure $(p<0.05)$ and mean arterial pressure $(p<0.05)$. Mann-Whitney $U$-test revealed that $80.54 \%$ cells with tails and mean DNA migration length of $50.01 \pm 1.01 \mu \mathrm{m}$ were significantly higher $(p<0.001)$ in patients compared to controls $(27.21 \% ; 20.33 \pm 0.74 \mu \mathrm{m})$. These differences between male and female patients/controls were, however, non-significant. The differences for drug-usage and WHR were non-significant while BMI and blood pressure values revealed significant DNA damage differences. The physiological state of hypertension probably has the potential to cause genetic damage as assessed in the present study by the SCGE assay since DNA migration length and percent cells with tails were highly significant $(p=0.001)$ as compared to values in normo-tensive, healthy controls.
\end{abstract}

Key words Cells with tails, DNA migration length, Single cell gel electrophoresis, Hypertension.

Essential hypertension or the condition of elevated arterial blood pressure is a complex genetic trait caused by multiple susceptibility genes, the effects of which are modulated by geneenvironment and gene-gene interactions (Shaughnessy 2000). It is a common chronic condition associated with reduced life expectancy with a potential to accumulate DNA damage (Pero et al. 1976) probably resulting from reactive oxygen species (ROS) produced by xanthine oxidase, NADPH/NADH oxidases and nitric oxide synthetase which become increased in hypertension (Huie and Padmaja 1993). Also, the angiotension II gene has been found to be associated with free radicals formation (Schupp et al. 2007). Free radicals react to form peroxynitrite which is a potent cytotoxic oxidant that leads to peroxidation of lipids, degradation of DNA and oligonucleosomal fragmentation (Hemnani and Parihar 1998). ROS also increase nitric oxide that causes tissue injury, protein oxidation and DNA damage (Xu and Touyz 2006). The imbalance or impaired status of antioxidants and free radicals in hypertensive patients further makes them vulnerable to oxidative stress (Kashyap et al. 2005). Peripheral polymorphonuclear leukocytes (which generate reactive superoxide anions) participate in oxidative stress and inflammation in patients with hypertension (Alexander 1995, Rajagopalan et al. 1996, Kristal et al. 1998). The pathogenic outcome of oxidative stress is oxidative damage, a major cause of vascular injury in hypertension (Touyz and Schiffrin 2007). Moreover, oxidative stress can have damaging effects on the DNA, which in turn

\footnotetext{
* Corresponding author, e-mail: gandhig07@hotmail.com
} 
are associated with age-related changes and causation of cancer. Since oxidative stress is induced in the hypertensive state, it is pertinent to investigate whether DNA damage is also induced in the hypertensive patients. Gur et al. (2007) observed a positive correlation between increased oxidative damage in hypertensive subjects and urinary 8-hydroxy-2-deoxyguanosine (8-OHdG), a DNA damage marker. There was reported an increase in oxidative stress and a reduction in the activity of antioxidant mechanisms though independent of the blood pressure value in whole blood and mono nuclear peripheral cells of hypertensive subjects (Redon et al. 2003). The single cell electrophoresis (SCGE), or 'comet', assay is a sensitive method for assessing DNA effects (Griffiths et al. 2002) such as DNA lesions, single-strand breaks, double-strand breaks and alkali-labile sites. The relative simplicity of the comet assay and the varied cell types that can be used has proved it to be a versatile and powerful tool for studying DNA damage. As not many studies have come to light regarding the assessment of DNA damage in hypertensive subjects and hardly any in the Indian populations, the present study investigated DNA damage in peripheral blood leukocytes of individuals with essential hypertension using the alkaline single cell gel electrophoresis assay.

\section{Materials and methods}

\section{Subjects}

Individuals seeking medical attention for hypertension at the Health Centre of Guru Nanak Dev University, Amritsar, and healthy normo-tensive individuals of the same age, sex and socioeconomic status comprised the study group. The individuals were given an explanation about the nature of the study and those who voluntarily agreed and gave written informed consent, were requested for their personal details and blood samples. The study was cleared by the Institutional Ethics Committee. The information of the patients and of the control group was noted on a specially designed questionnaire. A family pedigree of up to 3-generations was also taken to check for familial hypertension. The study was conducted during Jan.-Sept., 2007. Anthropometric measurements (as per Weiner and Lourie 1981) for calculating BMI (body mass index), as well as blood pressure, mean arterial pressure and pulse pressure readings (average of 3 using a mercury sphygmomanometer) were recorded for each individual.

\section{Sample collection}

Finger-prick blood samples $(\sim 300 \mu \mathrm{l})$ were taken in heparin and phosphate-buffered saline and transported to the laboratory on ice. The Trypan-blue exclusion test revealed cell viability $>85 \%$ and so the samples were processed for the alkaline SCGE assay (Singh et al. 1988) as modified by Ahuja and Saran (1999) using locally available chemicals (Fine Chem. Ltd., Qualigens, SRL, Glaxo Laboratory, Ranbaxy Lab., India). Blood mixed with $0.5 \%$ low melting point agarose (LMPA) was layered onto plain glass microscope slides pre-coated with $1.0 \%$ normal melting point agarose (NMPA), followed by another $0.5 \%$ LMPA layer. The slides were then subjected to lysis $(\mathrm{pH}=10 ; 2.5 \mathrm{M} \mathrm{NaCl}, 100 \mathrm{mM}$ EDTA, $10 \mathrm{mM}$ Tris aminomethane, $12.0 \mathrm{~g} \mathrm{NaOH}$ pellets; the mixture was freshly added to $1 \%$ Trition X-100 and 10\% DMSO) to liberate DNA, followed by alkaline treatment in electrophoresis buffer ( $25 \mathrm{~min}$ in $300 \mathrm{mM} \mathrm{NaOH}, 1 \mathrm{mM}$ EDTA; pH>13), an electrophoretic run $(\mathrm{pH}>13.0 ; 300 \mathrm{~mA}, 25 \mathrm{~V} ; 20-25 \mathrm{~min} ; 0.8 \mathrm{~V} / \mathrm{cm})$, neutralization $(0.4 \mathrm{M}$ Tris, $\mathrm{pH}=7.5)$ and silver $\left(20 \% \mathrm{AgNO}_{3}\right)$ staining (Delincee 1995). The slides were manually scored (100 cells/sample viz. 50/slide) under a binocular microscope $(40 \times)$ for cells with tails; an ocular micrometer was used to measure the DNA migration/tail length which was calculated by subtracting the measurement of radius of the core/cell from the total length of the comet.

\section{Statistical analysis}

The data were non-parametric and the Mann-Whitney " $U$ " test was applied. A Chi-square test 


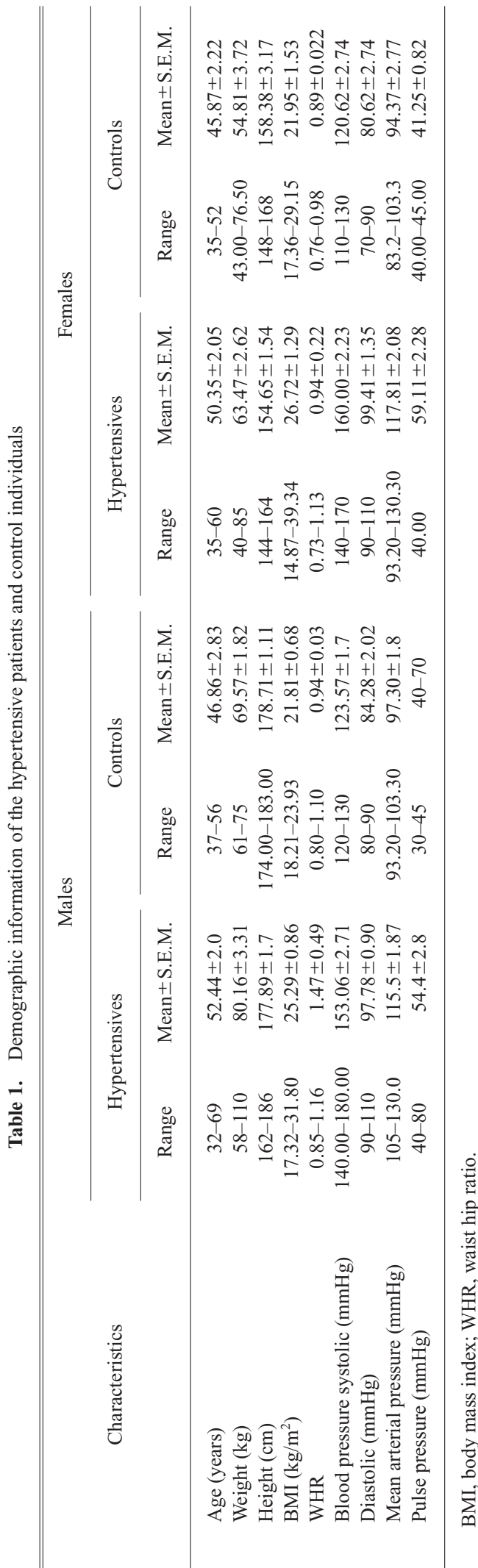

was performed to check whether the sample group matched the control. Multiple regression analysis and analysis of variance (ANOVA) was carried out to determine if confounding variables induced any DNA damage. The Mann-Whitney " $U$ " was also applied to find the significance within the factors associated with hypertension and DNA damage viz. BMI, blood pressure, etc. Results were taken as significant at $p<0.05$ and $p<0.001$.

\section{Results and discussion}

The patient group $(n=35)$ comprised individuals with systolic blood pressure $>140 \mathrm{mmHg}$ and diastolic blood pressure $>90 \mathrm{mmHg}(\mathrm{WHO} /$ ISH 2003). The control group $(n=15)$ comprised healthy individuals with no history of hypertension. The demographic information of the subjects $(n=50)$ is given in Table 1 . The hypertensive males $(n=18)$ were between $32-69$ years (mean 52.44 \pm 0.22 years) with average of $153.06 \pm$ $2.71 \mathrm{mmHg}$ systolic and $97.78 \pm 0.90 \mathrm{mmHg}$ diastolic blood pressure measurements. The 17 hypertensive females were between 35-59 years (mean 50.35 \pm 2.05 ) with systolic blood pressure of $140-170 \mathrm{mmHg}$ (mean $160 \pm 2.23 \mathrm{mmHg}$ ), and diastolic blood pressure $90-110 \mathrm{mmHg}$ (mean $99.41 \pm 1.35 \mathrm{mmHg}$ ) values. The control group comprised normotensive, healthy individuals $(n=$ 15; 7 males, 8 females; mean $46.33 \pm 1.71$ years; mean systolic blood pressure $122.00 \pm 1.68 \mathrm{mmHg}$; diastolic blood pressure $82.33 \pm 1.75 \mathrm{~mm}$ ). The personal attributes of the patients and controls are depicted in Table 2. The $2 \times 2$ Chi-square $\left(\chi^{2}\right)$ contingency test revealed that patient and control groups matched except for their age, blood pressure readings and BMI status. Multiple regression analysis showed a relationship between DNA damage and diastolic blood pressure, $(p=$ $0.039)$ and mean arterial pressure, $(p=0.041)$ in male patients and with BMI in controls. In the analysis of variance, significance was only observed for systolic blood pressure $(p=0.047)$ in combined patient group.

\section{DNA damage}

Genetic damage was scored as per cent cells with tails and DNA migration length. An initial analysis of results separately for males (in patient 
Table 2. Personal attributes and Chi square $\left(\chi^{2}\right)$ analysis of hypertensive patients and normal control individuals

\begin{tabular}{|c|c|c|c|c|c|c|}
\hline Attributes & Range & $\begin{array}{l}\text { Patient } \\
\text { group }\end{array}$ & $\begin{array}{l}\text { Control } \\
\text { group }\end{array}$ & $\chi_{\text {cal }}^{2}$ & $\chi_{\text {tab }}^{2}$ & \\
\hline \multirow[t]{2}{*}{ Age range (years) } & $32-50$ & 14 & 11 & 4.670 & 3.84 & $\mathrm{~S}$ \\
\hline & $51-69$ & 21 & 4 & & & \\
\hline \multirow[t]{2}{*}{ Dietary pattern } & Veg & 19 & 9 & 0.139 & 3.84 & NS \\
\hline & Non veg & 16 & 6 & & & \\
\hline \multirow[t]{2}{*}{ Mobile phone users } & User & 15 & 7 & 0.062 & 3.84 & NS \\
\hline & Non user & 20 & 8 & & & \\
\hline \multirow[t]{2}{*}{ Alcohol consumption } & Drinker & 10 & 3 & 0.400 & 3.84 & NS \\
\hline & Non drinker & 25 & 12 & & & \\
\hline \multirow[t]{2}{*}{ BMI $\left(\mathrm{kg} / \mathrm{m}^{2}\right)$} & $<18.5-24.5$ & 10 & 13 & 14.26 & 3.84 & $\mathrm{~S}$ \\
\hline & $25.5-31.5$ & 25 & 2 & & & \\
\hline \multirow[t]{3}{*}{ Systolic blood pressure (mmHg) } & $>120-139$ & 0 & 15 & 50.00 & 9.49 & $\mathrm{~S}$ \\
\hline & $140-159$ & 16 & 0 & & & \\
\hline & $160-179$ & 19 & 0 & & & \\
\hline \multirow{3}{*}{ Diastolic blood pressure $(\mathrm{mmHg})$} & $70-89$ & 0 & 10 & 29.69 & 9.49 & $\mathrm{~S}$ \\
\hline & $90-100$ & 29 & 5 & & & \\
\hline & $101-111$ & 6 & 0 & & & \\
\hline \multirow[t]{2}{*}{ Mean arterial pressure $(\mathrm{mmHg})$} & $93.2-113.2$ & 12 & 15 & 50.70 & 3.84 & $\mathrm{~S}$ \\
\hline & $114.2-134.2$ & 23 & 0 & & & \\
\hline \multirow{2}{*}{ Pulse pressure (mmHg) } & $40-55$ & 17 & 15 & 12.05 & 3.84 & $\mathrm{~S}$ \\
\hline & $56-71$ & 18 & 0 & & & \\
\hline \multirow[t]{2}{*}{ Waist hip ratio } & $0.8-0.96$ & 17 & 11 & 2.61 & 3.84 & NS \\
\hline & $0.97-1.13$ & 18 & 4 & & & \\
\hline
\end{tabular}

NS, not significant; S, significant; BMI, body mass index.

Table 3. DNA damage in hypertensive and control individuals

\begin{tabular}{|c|c|c|c|c|c|}
\hline Groups & & $\begin{array}{l}\text { Cells with } \\
\text { tails/cells } \\
\text { scored (\%) }\end{array}$ & $\begin{array}{l}\text { Pooled cells } \\
\text { with tails/cells } \\
\text { scored }(\%)\end{array}$ & $\begin{array}{c}\text { Mean DNA } \\
\text { migration } \\
\text { length } \\
(\mu \mathrm{m}) \pm \text { S.E.M. }\end{array}$ & $\begin{array}{c}\text { Pooled mean } \\
\text { DNA migration } \\
\text { length } \\
(\mu \mathrm{m}) \pm \text { S.E.M. }\end{array}$ \\
\hline \multirow[t]{2}{*}{ Hypertensive individuals } & $\begin{array}{l}\text { Males } \\
(n=18)\end{array}$ & $\begin{array}{c}1401 / 1800 \\
\left(79.33^{* *, a, b}\right)\end{array}$ & $\begin{array}{c}2791 / 3500 \\
(80.54 * *)\end{array}$ & $50.74 \pm 1.18^{* *, a, b}$ & $50.01 \pm 1.01 * *$ \\
\hline & $\begin{array}{c}\text { Females } \\
(n=17)\end{array}$ & $\begin{array}{c}1390 / 1700 \\
\left(81.76^{* *, a, b}\right)\end{array}$ & & $49.28 \pm 0.85^{* *, a, b}$ & \\
\hline \multirow[t]{2}{*}{ Control individuals } & $\begin{array}{l}\text { Males } \\
(n=7)\end{array}$ & $\begin{array}{l}181 / 700 \\
\left(25.80^{\mathrm{b}}\right)\end{array}$ & $\begin{array}{c}410 / 1500 \\
(27.21)\end{array}$ & $19.95 \pm 0.76^{b}$ & $20.33 \pm 0.74$ \\
\hline & $\begin{array}{c}\text { Females } \\
(n=8)\end{array}$ & $\begin{array}{l}229 / 800 \\
\left(28.62^{\mathrm{b}}\right)\end{array}$ & & $20.71 \pm 0.73^{b}$ & \\
\hline
\end{tabular}

** Highly significant when compared with total control group ( $p \leq 0.001$, Mann-Whitney $U$-test).

${ }^{a}$ Highly significant when compared with parallel control group ( $p \leq 0.001$, Mann-Whitney $U$-test).

${ }^{\mathrm{b}}$ Non-significant compared to each other. 

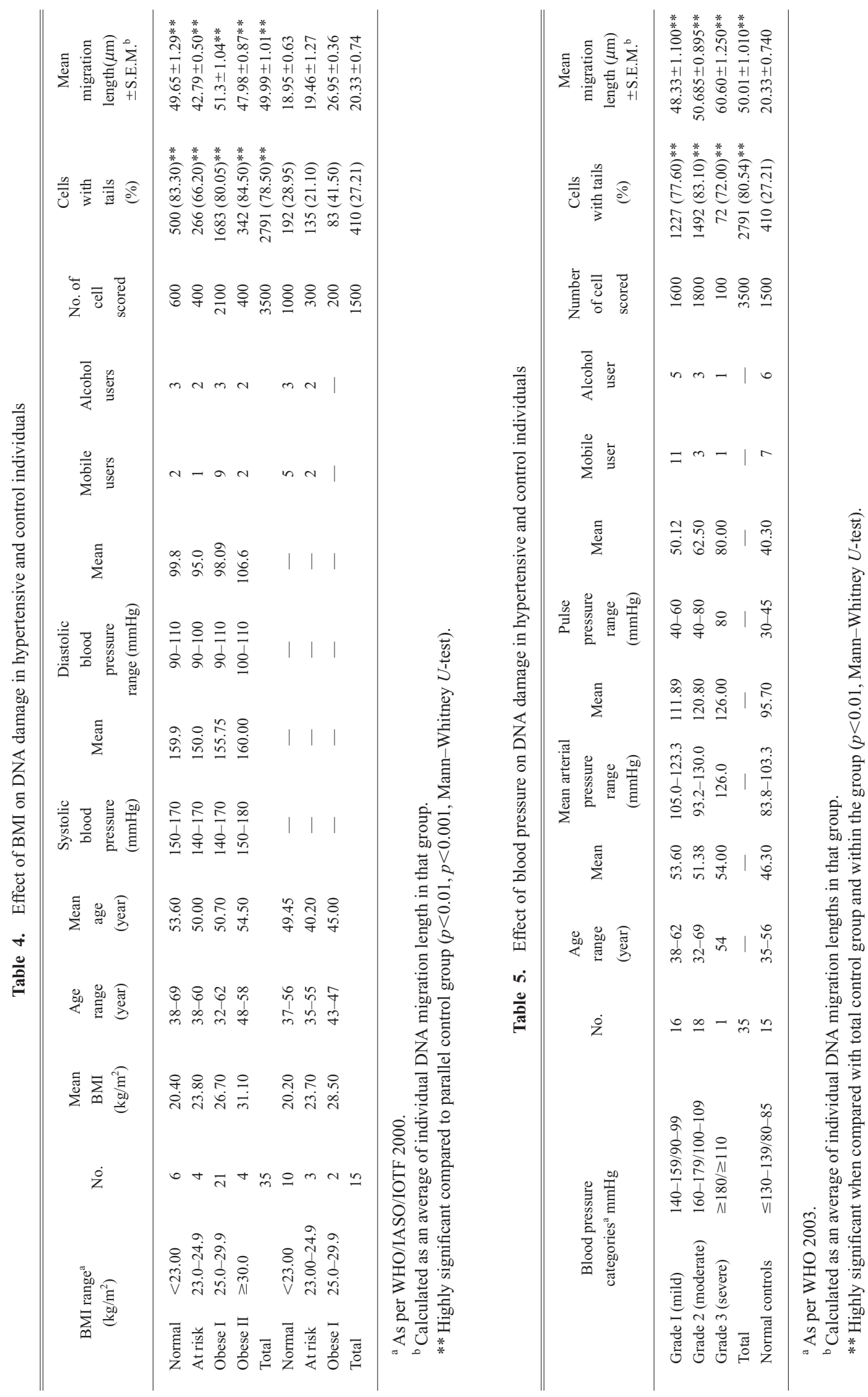


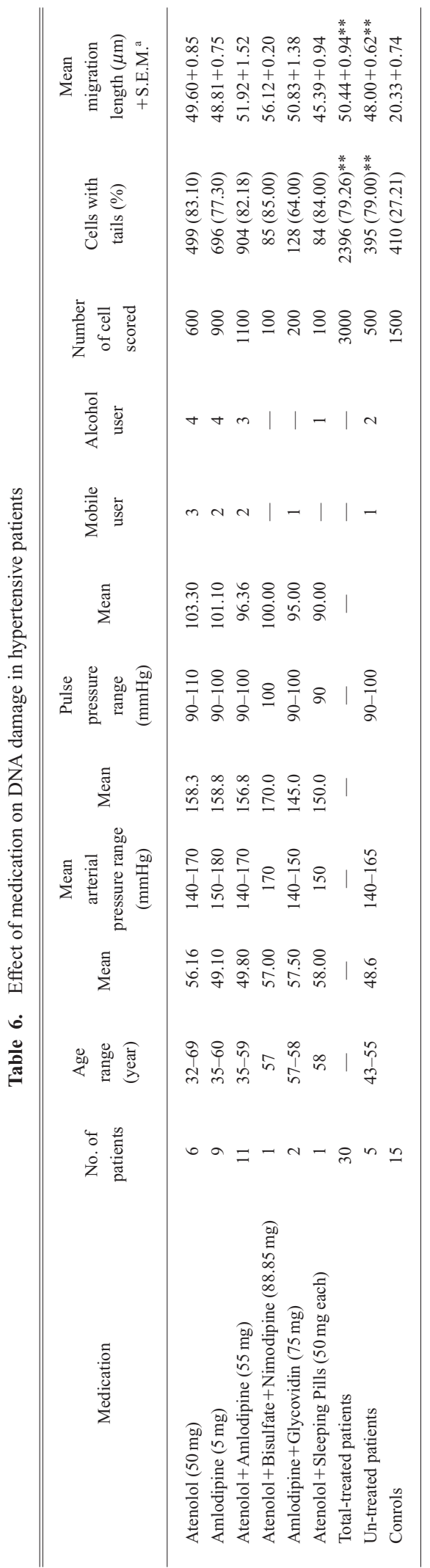

and control groups) and for females (in patient and control groups) revealed statistical significance for both DNA migration and per cent cells with tails though no significant increase was observed for different age ranges (Gandhi and Jyoti 2010). However, the differences between male and female patients were not significant for either per cent cells with tails $\left(Z_{\text {cal }}=1.174, Z_{\text {tab }}=2.576 ; p=0.241\right)$ or DNA migration length $\left(Z_{\mathrm{cal}}=1.023, Z_{\mathrm{tab}}=2.576\right.$, $p=0.306$ ); neither were these respective values significant in the control males and females $\left(Z_{\mathrm{cal}}=\right.$ $0.406, Z_{\mathrm{tab}}=2.576, p=0.685 ; Z_{\mathrm{cal}}=0.465, Z_{\mathrm{tab}}=$ $2.576, p=0.645)$. Hence these values for females and males (Table 3 ) were pooled in both (control and patient) groups. These combined values on analysis revealed statistical significance with each other $\left(Z_{\mathrm{cal}}=5.561, Z_{\mathrm{tab}}=3.291, p<0.001 ; Z_{\mathrm{cal}}=\right.$ 5.262, $\left.Z_{\mathrm{tab}}=3.291, p<0.001\right)$ indicating significant genetic damage in hypertensive patients compared to healthy controls.

\section{Effect of body mass index (BMI)}

BMI is an indicator of a risk factor for hypertension (Feldstein et al. 2005). Endothelial dysfunction and hypertension may be related to chronic oxidative stress induced by obesity and therefore BMI and WHR can be related with significant DNA damage. Krajcovicova et al. (2007) observed that with increase in age, BMI values increased as did DNA damage. A longitudinal association of BMI and oxidative DNA damage (8-OHdG levels) in 174 individuals has also been reported (Mizoue et al. 2007). Kasai et al. (2001) had investigated an association of BMI with other life style patterns like smoking and meat intake with DNA damage and their results revealed significant reduction in urinary $8-\mathrm{OHdG}$ level with increase in BMI. In the present study, patients and controls were categorized for BMI as per WHO criteria (2000). There were significant differences (Table 4) between 2 ranges (23.00 $24.90 \mathrm{~kg} / \mathrm{m}^{2}$ and $25.0-29.9 \mathrm{~kg} / \mathrm{m}^{2}$ ) for both, increased percentage of cells with tails $\left(t_{\mathrm{cal}}=\right.$ 2.529, $\left.t_{\mathrm{tab}}=2.450, d f=6 ; p=0.045\right)$ and increased mean DNA migration length $\left(t_{\mathrm{cal}}=2.968, t_{\mathrm{tab}}=\right.$ $2.070, \quad d f=23 ; \quad p=0.007)$ and between the categories $<23.00 \mathrm{~kg} / \mathrm{m}^{2}$ and $23.00-24.90 \mathrm{~kg} / \mathrm{m}^{2}$ for increased mean DNA migration length only $\left(t_{\mathrm{cal}}=2.506, t_{\mathrm{tab}}=2.310, d f=8, p=0.030\right)$. 


\section{Effect of blood pressure}

Increased blood pressure has vulnerability to oxidative stress (Kashyap et al. 2005) and a relationship between 8-OHdG level and hypertension has been reported (Negishi et al. 2001). Hypertension is also associated with increased ROS formation (Harrison et al. 2007) and these ROS cause oxidative stress which reduces the level of vasodilators and nitric oxide, and thereby cause tissue injury and DNA damage (Xu and Touyz 2006). In the present study, the per cent cells with tails and mean DNA migration length showed significant differences between different ranges of blood pressure (Table 5). The damage continuously increased with increase in blood pressure values (ranges according to WHO 2003). For cells with tails, the ranges between $140-159 \mathrm{mmHg} /$ $90-99 \mathrm{mmHg}$ and $160-179 \mathrm{mmHg} / 100-109 \mathrm{mmHg}\left(t_{\mathrm{cal}}=10.862, t_{\mathrm{tab}}=3.290, d f=32, p=0.001\right)$, between $140-159 \mathrm{mmHg} / 90-99 \mathrm{mmHg}$ and $\geq 180 \mathrm{mmHg} / \geq 110 \mathrm{mmHg} \quad\left(t_{\mathrm{cal}}=7.034, t_{\mathrm{tab}}=4.070\right.$, $d f=15, p=0.001)$ and between $160-179 \mathrm{mmHg} / 100-109 \mathrm{mmHg}$ and $\geq 180 \mathrm{mmHg} / \geq 110 \mathrm{mmHg}$ $\left(t_{\mathrm{cal}}=21.21, t_{\mathrm{tab}}=3.29, d f=31, p=0.001\right)$. For mean DNA migration length, a significant difference was observed for blood pressure ranges $160-170 \mathrm{mmHg} / 100-109 \mathrm{mmHg}$ and $\geq 180 \mathrm{mmHg} / \geq 110$ $\mathrm{mmHg}\left(t_{\mathrm{cal}}=2.162, t_{\mathrm{tab}}=1.96, d f=31, p=0.001\right)$ and for ranges between $150-159 / 90-99 \mathrm{mmHg}$ and $\geq 180 / \geq 110 \mathrm{mmHg}\left(t_{\mathrm{cal}} \leqq 2.80, t_{\mathrm{tab}}=2.13, d f=15 ; p=0.06\right)$.

\section{Effect of medication}

During the interval when this study was conducted, most of the patients $(n=30)$ were on antihypertensive medications (Table 6). As per WHO recommendation (2005), 6 main classes of drugs prescribed worldwide are diuretics, $\beta$-blockers, angiotensin converting enzyme inhibitors, calcium antagonists, $\alpha$-blockers and angiotensin II antagonists. In the University Health Care Centre, Amritsar mainly $\beta$-blockers (Atenolol- $\mathrm{C}_{14} \mathrm{H}_{22} \mathrm{~N}_{12} \mathrm{O}_{3}$ ) and calcium channel blockers (Amlodipine$\mathrm{C}_{20} \mathrm{H}_{25} \mathrm{ClN}_{2} \mathrm{O}_{5}$ and Nimodipine- $\mathrm{C}_{14} \mathrm{H}_{25} \mathrm{~N}_{7} \mathrm{O}_{7}$ ) are prescribed. Literature perusal has revealed that amlodipine, induced neither mutagenicity in bacteria nor chromosomal aberrations in mice (Ahr et al. 1997). It significantly inhibited lipid peroxidation which is the main cause of oxidative stress and reactive oxygen species formation (Harrison et al. 2007) and Nimodipine also appeared to inhibit lipid peroxidation but not statistically. Mason et al. (1999) also showed that Amlodipine inhibited nuclear changes associated with apoptosis, including chromatin condensation and internucleosomal DNA cleavage at low or nanomolar levels, and induced neuroprotective activity and decreased reactive oxygen species formation. Andereassi et al. (1999) also reported that calcium antagonists did not induce cytogenetic damage in peripheral blood lymphocyte cultures. Atenolol, however mainly induced chromosomal loss, especially of chromosome 17 (Telez et al. 2000, 2003), and Nimodipine also induced micronuclei production (Telez et al. 2001). Saez et al. (2004) observed that there was increased oxidative stress and decreased antioxidant mechanism in patients taking antihypertensive drugs. However in the present study, the results did not reveal significant DNA damage between treated ( $79.26 \%$ cells with tails; mean migration length of $50.44 \pm 0.94 \mu \mathrm{m})$ and the untreated $(79.00 \%$ cells with tails; mean migration length $48.00 \pm 0.62 \mu \mathrm{m})$ patient groups, probably because of the small number of untreated patients $(n=5)$ as compared to treated patients $(n=30)$ and also perhaps because of their different lifestyles. The damage observed has probably resulted from the increased blood pressure values themselves since damage was much lower in normo-tensive (control) group. Antihypertensive agents $(\beta$-adrenergic blockers, ACE inhibitors, $\mathrm{AT}_{1}$ receptor antagonists, and $\mathrm{Ca}^{2+}$-channel blockers may be mediated in part by decreasing vascular oxidative stress (Godfraind 2005, Cifuentes and Pagano 2006, Flammer et al. 2007) and Grossmann (2008) has concluded that lowering blood pressure with antihypertensive medications is associated with reduced oxidative stress and so oxygen stress is probably not the cause, but rather a consequence of, hypertension.

Individuals with essential hypertension are vulnerable to oxidative stress (because of an imbalanced status of antioxidants and free radicals) and to oxidative and DNA damage (Kashyap et 
al. 2005, Xu and Touyz 2006). In the present study, DNA damage was highly significant ( $p \leq 0.001)$ in patient samples. The damage may be resulting from the state of hypertensiveness via reactive oxygen species since these are both a consequence and cause of hypertension (Huie and Padmaja 1993). Angiotension II has also been found to be associated with free radical formation by activation of the NADPH oxidase enzyme that can cause DNA damage via Ang II type I receptor binding and the subsequent formation of oxidative stress (Schupp et al. 2007). An increase in the level of 8-hydroxy guanine (8-OHdG) is also an indicator of the relationship between oxidative DNA damage, hypertension and cardiovascular disease risk (Negishi et al. 2000). A vegetarian diet/supplementation can provide some protection against oxidative stress and so decrease oxidative DNA damage (Kazimirova et al. 2004, Dhawan and Jain 2005, Krajcovicova et al. 2007). Confounding factors like alcohol consumption and mobile use can also cause DNA damage (Zhu et al. 2002, Gandhi and Anita 2005). Furthermore, pulse pressure significantly increased with increase in WHR and caused oxidative stress (Feldstein et al. 2005). Our sample group also had 24 patients with a WHR $>0.92-1.12$ in the higher BMI range. Increases in age and BMI also increased DNA damage (Krajcovicova et al. 2007) and a longitudinal association of BMI and oxidative DNA damage has been also documented (Mizoue et al. 2007). Hypertension is a leading risk factor for cerebrovascular, cardiovascular and renal problems (Kashyap et al. 2005) and the results of the present study highlight that damage to genetic material is also elevated in patients with essential hypertension. As generation of DNA damage is considered to be an important initial event in carcinogenesis, the observed DNA damage hence may have other far-reaching consequences as it can further contribute to the risk of development of degenerative and mitochondrial diseases as well as neoplasia. Interventions aimed at increasing the antioxidant defense system and reducing oxidative stress may prove useful for mitigating these outcomes in hypertensive patients.

\section{Acknowledgements}

Part of the work was carried out with a grant from PSCST awarded to JJ.

\section{References}

Ahr, H. J., Bomhar, E., Mager, H. and Schluter, G. 1997. Calcium channel blockers and cancer: is there preclinical evidence for an association? Cardiology 88: 68-72.

Ahuja, Y. R. and Saran, R. 1999. Alkaline single cell gel electrophoresis assay I. Protocol. Cytol. Genet. 34: 57-62.

Alexander, R. W. 1995. Hypertension and the pathogenesis of atherosclerosis. Oxidative stress and the mediation of arterial inflammatory response: a new perspective. Hypertension 25: 155-161.

Andereassi, M., Picano, E., Del, S. and Vorga, A. 1999. Effect of chronic long-term therapy with calcium antagonists on cytogenetic damage in humans. J. Hyperten. 17: 843-846.

Cifuentes, M. E. and Pagano P. J. 2006. Targeting reactive oxygen species in hypertension. Curr. Opin. Nephrol. Hypertens. 15: $179-186$.

Delincee, H. 1995. Silver staining of DNA in the comet assay. Comet Newslett. \#3.

Dhawan, V. and Jain, S. 2005. Garlic supplementation prevents oxidative DNA damage in essential hypertension. Mol. Cell Biochem. 1275: 85-94.

Feldstein, C. A., Akopian, M., Olivieri, A. O., Kramer, A. P., Nasi, M. and Garrido, D. 2005. A comparison of body mass index and waist-to-hip ratio as indicators of hypertension risk in an urban Argentine population: a hospital-based study. Nutr. Metab. Cardiovasc. Dis. 15: 310-315.

Flammer, A.J., Hermann, F., Wiesli, P., Schwegler, B., Chenevard, R., Hürlimann, D., Sudano, I., Gay, S., Neidhart, M., Riesen, W., Ruschitzka, F., Lüscher, T. F., Noll, G. and Lehmann, R. 2007. Effect of losartan, compared with atenolol, on endothelial function and oxidative stress in patients with type 2 diabetes and hypertension. J. Hypertens. 25: 785-791.

Gandhi, G. and Anita 2005. Genetic damage in Mobile Phone users: Some preliminary findings. Ind. J. Hum. Gen. 11: 99-104

— and Jyoti, J. 2010. DNA Damage using the Single Cell Gel Electrophoresis Assay in Individuals Diagnosed with 
Essential Hypertension. Proceedings National Seminar on "Anthropology and Society: Issues and Applications" Department of Anthropology, Panjab University, Chandigarh, India (in press).

Godfraind, T. 2005. Antioxidant effects and the therapeutic mode of action of calcium channel blockers in hypertension and atherosclerosis. Philos. Trans. R. Soc. Lond. B Biol. Sci. 360: 2259-2272.

Griffiths, H. R., Moller, L., Bartosz, G., Bast, A., Bertoni-Freddari, C., Collins, A., Cooke, M., Haenen, G., Hoberg, A. M., Loft S., Lunec J., Olinski, R., Parry, J., Pompella, A., Poulsen, H., Verhagen, H. and Astley, S. B. 2002. Biomarkers. Mol. Aspects Medicine 23: 101-208.

Grossman, E. 2008. Does Increased Oxidative Stress Cause Hypertension? Diabetes Care 31 (Supple. 2): S185-S189.

Gur, M., Yildiz, A., Demirbag, R., Yilmaz, R., Kocyigit, A., Celik, H. and Aksay, N. 2007. Relationship between left ventricle geometric patterns and lymphocyte DNA damage in patient with untreated essential hypertension. Clin. Biochem. 40: 454-459.

Harrison, D., Gongara, M., Guzik, T. and Widder, J. 2007. Oxidative stress and hypertension. J. Am. Soc. Hyperten. 1: 30-44.

Hemnani, T. and Parihar, M. S. 1998. Reactive oxygen species and oxidative DNA damage. Ind. J. Physiol. Pharmacol. 42: $440-452$.

Huie, R. F. and Padmaja, S. 1993. The reaction of NO with superoxide. Free Rad. Res. Commun. 18: 195-199.

Kasai, H., Iwamoto-Tanaka, N., Miyamoto, T., Kawanami, K., Kawanami, S., Kido, R. and Ikeda M. 2001. Life style and urinary 8-hydroxydeoxyguanosine, a marker of oxidative DNA damage: effects of exercise, working conditions, meat intake, body mass index, and smoking. Jpn. J. Cancer Res. 92: 9-15.

Kashyap, M., Yadav, V., Sherawat, B., Jain, S., Kumari, S., Khullar, M., Sharma, P. and Nath, R. 2005. Different antioxidants status, total antioxidant power and free radicals in essential hypertension. Mol. Cell Biochem. 277: 89-99.

Kazimirova, A., Barancokova, M., Volkovova, K., Staruchová, M., Krajoviová-Kudláková, M., Wsólová, L., Collins, A. R. and Duinská, M. 2004. Does a vegetarian diet influence genomic stability? Eur. J. Nutr. 43: 32-38.

Krajcovicova-Kudlackova, M., Babinska, K., Valachovicova, M., Paukova, V., Dusinska, M. and Blazicek, P. 2007. Vitamin C protective plasma value. Bratisl Lek Listy. 108: 265-268.

Kristal, B., Shurta-Swirrski, R. and Chezar, J. 1998. Participation of peripheral polymorphonuclear leukocytes in the oxidative stress and inflammation in patients with essential hypertension. Am. J. Hypertens. 11: 921-928.

Mason, P. R., Leeds, P., Jacob, R., Hough, C., Zhang, K., Mason, P. E. and Chuang, D. M. 1999. Inhibition of exercise neuronal apoptosis by the calcium antagonist amlodipine and antioxidant in cerebellar granule cells. J. Neurochem. 72: 1448-1456.

Mizoue, T., Tokunaga, S., Kasai, H., Kawai, K., Sato, M. and Kubo, T. 2007. Body mass index and oxidative DNA damage: A longitudinal study. Cancer Sci. 98: 1254-1258.

Negishi, H., Ikeda, K., Kuga, S., Noguch, T., Kanda, T., Mielekela, H., Liut, and Miki, T. 2001. The relation of oxidative DNA damage to hypertension and other cardiovascular risk factors in Tanzania. J. Hyperten. 19: 529-533.

-, Njelekela, M., Ikeda, K. and Sagara, M. 2000. Assessment of in vivo oxidative stress in hypertensive rats and hypertensive subject in Tanzania, Africa. Hyperten. Res. 23: 285-289.

Pero, R., Bryngelsson, C., Mitelman, F., Thulin, T. and Norden, A. 1976. High blood pressure related to carcinogen-induced unscheduled DNA synthesis, DNA carcinogen binding, and chromosomal aberrations in human lymphocytes. Proc. Natl. Acad. Sci. 73: 2496-2500.

Rajagopalan, S., Meng, X. P., Ramasamy, S., Harrison, D. G. and Galis Z. S. 1996. Reactive oxygen species produced by macrophage-derived foam cells regulate the activity of vascular matrix metalloproteinases in vitro. J. Clin. Invest. 98: 2572-2579.

Redon, J., Maria, O., Carmen, T. and Vicente, G. 2003. Antioxidant Activities and Oxidative Stress Byproducts in Human Hypertension. Hypertension 41: 1096-1101.

Saez, G. T., Tormos, C., Giner, V., Chaves, J., Lozano, J. V., Iradi, A. and Redon, J. 2004. Factors related to the impact of antihypertensive treatment in antioxidant activities and oxidative stress by-product in human hypertension. Am. J. Hyperten. 17: 809-816.

Schupp, N., Schmid, U., Rotkowski, P., Laknes, V., Kenase, N. and Heidland, A. 2007. Angiotensin II-induced genomic damage in renal cells can be prevented by angiotensin II type-I receptor blockage or radical scavenging. Am. J. Physiol. Renal Physiol. 16: 1-5.

Shaughnessy, K. 2000. The genetics of essential hypertension. Br. J. Clin. Pharmacol. 51: 5-11.

Singh, N. P., McCoy, M. T., Tice, R. R. and Schneider, E. L. 1988. A simple technique for quantitation of low levels of DNA damage in individual cells. Exp. Cell Res. 175: 184-191.

Telez, M., Martinez, B., Cariodo, B., Lastao, C. M., Ortega, B., Flores, P. and Isobel, A. 2000. In vitro and in vivo evaluation of antihypertensive drug atenolol in cultured human lymphocytes: effect of long-term therapy. Mutagenesis $\mathbf{1 5}$ 195-202.

- - - - Ortega, B. and Flores, P. 2001. Evaluation of cytogenetic damage induced by the antihypertensive drug nomodipine in human lymphocytes. Mutagenesis 16: 345-351. 
—, Penagarikaro, O., Ortega, B., Marcos, A., Montero, C., Cariodo, B. and Flores, P. 2003. Preferential exclusion of chromosome 17 in hypertensive patients treated with atenolol: review of the toxicological data obtained with this drug. 4th European Cytogenetic Conference, Bolonga, Italy.

Touyz, R. M. and Schiffrin, E. L. 2007. Oxidative stress and Hypertension. In: Holtzman, J. L. (ed.). Atherosclerosis and Oxidant Stress: A New Perspective. Springer Heidelberg. pp. 51-77.

Weiner, J. S. and Lourie, J. A. 1981. Human Biology: A Guide to Field Methods. Practical Human Biology, Academic Press Inc., New York.

WHO 2005. Pharmacy-Based Hypertension Management Model: Protocol and Guidelines. A joint CINDI/EuroPharm Forum project (www.euro.who.int/Document/E85730.pdf).

WHO/IASO/IOTF 2000. The Asia-Pacific Perspective: Redefining Obesity and its Treatment. Health Communications Australia., Melbourne.

WHO/International Society of Hypertension (ISH) 2003. Statement on management of hypertension. The updated hypertension Guidelines. J. Hypertens. 21: 1983-1992.

Xu, S. and Touyz, R. M. 2006. Reactive oxygen species and vascular re-modelling in hypertension: still alive. Can. Cardiol. 22: 947-951.

Zhu, C. Q., Lam, T. H., Jiang, C. Q., Wei, B. X., Xu, Q. R. and Chen, Y. H. 2002. Increased lymphocyte DNA strand breaks in rubber workers. Mutat. Res. 470: 201-209. 